\title{
AN OVERVIEW OF STATUTES RELATING TO CIVIL PROCEDURE IN SOUTH AFRICA IN LIGHT OF THE CHANGES IN TECHNOLOGY ${ }^{1}$
}

\author{
Nombulelo Queen Mabeka \\ LLB LLM LLD \\ Senior Lecturer, Department of Jurisprudence \\ University of South Africa (UNISA) \\ Rushiella Songca \\ BA LLB LLM LLM LLD \\ Professor, Walter Sisulu University (WSU)
}

\section{SUMMARY}

E-technology has fast become an acceptable and convenient method of communication and a prerequisite of business transactions globally. South Africa is no exception to the trend. While technological progress has facilitated rapid change in the way humans communicate and transact. South African law has not kept abreast of the swift transformation and growth in this sector. This lacuna is especially evident in the South African law of civil procedure, which regulates the civil process in South African courts. Although subject to regular amendment, it appears prima facie not to embrace advances in e-technology and their effect - or potential effect on the legal process.

Moreover, the existing corpus of legislation governing civil process appears to have disregarded the provisions of the Electronic Communications and Transactions Act (ECTA) to the extent that it already provides mechanisms for the use of etechnology. In South Africa, the law of civil procedure is regulated by statutes such as the Rules Board for Courts of Law Act, the Superior Courts Act, the Magistrates' Courts Act, the Sheriffs Act, the National Credit Act, the Small Claims Court Act, and the Divorce Act, which inter alia regulate court process and ensure the fair administration of justice. The submission made here explores this indicated gap within selected legislation pertinent to civil procedure and postulates the effect of etechnology in the context of the abovementioned legislation.

As an example, section 35 of the Superior Courts Act indicates that parties and witnesses must make a physical appearance in the court of issue. This provision, however, does not expressly allow for the use of video conferencing, which would enable witnesses to give evidence via e-technology, and thus allow parties to investigate and re-examine witnesses situated in any geographical location outside of

This article is part of an LLD thesis by NQ Mabeka, supervised by R Songca and V Basdeo on The Impact of E-Technology on the Law of Civil Procedure (Doctoral thesis, University of South Africa) 2018 hereinafter referred to as Mabeka Impact of E-Technology). 
court. Further, section $74 \mathrm{Q}$ of the Magistrates' Courts Act makes it mandatory for garnishee orders to be served personally or by registered mail. This provision is not in line with developments in e-technology. Email, Facebook, or other digital means of service could facilitate the service of garnishee orders issued by magistrates' courts more effectively and remove delays posed by slow postal delivery, and also inhibit the prohibitive cost of personal service. With this contribution, select statutory provisions are compared to ECTA provisions and specific e-technology laws so as to determine the extent of the gap in the implementation of e-technology within the sphere of civil process. The authors then provide insights into how the current civil law statutes could be amended in line with selected e-technology legislation discussed here.

\section{$1 \quad$ INTRODUCTION}

E-technology is fast becoming a regular mode of communication, and its effective use in business globally cannot be denied. South African statutes that regulate the law of civil procedure (to wit, the Superior Courts $\mathrm{Act}^{2}$ (SC Act), the Magistrates' Courts Act ${ }^{3}$ (MCA), the Small Claims Court Act ${ }^{4}$ (SCC Act), and the National Credit Act ${ }^{5}(\mathrm{NCA})$ ) are regularly amended; yet the amendments do not appear to embrace e-technology fully in civil proceedings in line with the rapid expansion and pervasive impact of $e$ technology. For example, the MCA still requires that service be effected via sheriff, ${ }^{6}$ which includes processes relating to the issuing of automatic rent interdicts ${ }^{7}$ and hypothecs. In these instances, if the sheriff does not submit a certificate of service, he/she may be subjected to disciplinary proceedings in terms of the Sheriffs Act $(S A)^{8}$ even though sheriffs and legal representatives can invoke electronic means of service if the legislation is amended to this effect. By way of further example, the $\mathrm{NCA}^{9}$ requires parties first to issue a notice to a defaulting party at the last known address before the institution of court processes. ${ }^{10}$ The authors argue that this mode of service is outdated and could be more effectively arranged via Facebook,

10 of 2013.

32 of 1944 .

61 of 1984 .

34 of 2005.

Anthony and Berryman Magistrates' Court Guide (2019) 1145-1183; Magistrates' Court Act 32 of 1944; Broodryk Eckard's Principles of Civil Procedure in the Magistrates' Courts 6ed (2019) 1-438; Cilliers, Loots and Nel Herbstein and Van Winsen: The Civil Practice of the High Courts and the Supreme Court of Appeal of South Africa (2009) 1-2000; Erasmus and Van Loggerenberg Jones and Buckle: The Civil Practice of the Magistrates' Court in South Africa 10ed (2017) 21-80; Kelbrick and Cassim Civil Procedure in South Africa (2018) 1146; Faris and Hurter The Student Handbook for Civil Procedure 7ed (2015) 344-345; Peté, Du Plessis and Sibanda Civil Procedure: A Practical Guide - Procedural Law 3ed (2017) 52-268.

7 S 31 of the MCA.

890 of 1986, s 3; see the Uniform Rules of Court 2009; Rules Regulating the Conduct of the proceedings of the Magistrate's Court of South Africa No.R740 (23 August 2010) (herein after referred to as the Magistrate's Court Rules).

9 S 29.

10 S 129-130; see also Mabeka Impact of E-Technology 66-69. 
Instagram, email and other digital e-technology devices. ${ }^{11}$ South African courts recognise the use of e-technology and allow for parties to serve by way of Facebook, ${ }^{12}$ but it appears that the legislation is unclear in this regard.

In light of the above summary anecdotal examples, this contribution examines selected civil process legislation and makes recommendations for their potential development and eventual amendment so as to align them with developments in e-technology and the expanding branch of etechnology law. The authors begin by discussing the Constitution Seventeenth Amendment Act of 2012 (CSA), the Rules Board for Courts of Law $\mathrm{Act}^{13}$ (RBCL Act) and the SC Act. In addition, the contribution analyses the MCA, the NCA, the SCC Act, the SA, the Consumer Protection Act ${ }^{14}$ (CPA), the Divorce Act ${ }^{15}$ and the Electronic Communications and Transactions $\mathrm{Act}^{16}$ (ECTA), as they relate to the overall hypothesis of the submission.

\section{THE CONSTITUTION SEVENTEENTH AMENDMENT ACT OF 2012 (CSA)}

The unamended section 167 of the CSA entrenched the Constitutional Court structure and expanded on the duties of its staff. It stated that the Constitutional Court is the highest court that may decide on constitutional matters. ${ }^{17}$ The use of the word "may" in this section, however, denoted that this provision was not mandatory, and hence, there was a need to amend it to enforce the supremacy of the Constitution. ${ }^{18}$ Section 167 was thus amended in 2012 to solidify the hierarchy of the South African court structure. ${ }^{19}$ This amendment emanated from a need to ensure that there is one court of final instance where all constitutional matters are finalised ${ }^{20}$ and thus ensure finality, which is one of the basic principles of procedural law.

In terms of the CSA, parliament amended the Constitution to illustrate that the Constitutional Court is now the apex court, ${ }^{21}$ meaning that it is the

11 Papadopoulos and Snail Cyberlaw@SA111: The Law of the Internet in South Africa (2012) 1-3320.

12 CMC Woodworking Machinery v Odendaal Kitchens 2012 (5) SA 604 (KZD).

13107 of 1985.

1466 of 2008.

1570 of 1979.

1625 of 2002 .

17 The Constitution Seventeenth Amendment Act of 2012 (CSA); Kleyn and Viljoen Beginner's Guide for Law Students 5ed (2018) 85; Peté et al Civil Procedure: A Practical Guide Procedural Law 351.

18 Cockram Interpretation of Statutes 3ed (1987) 1-22; De Ville Constitutional and Statutory Interpretation 1ed (2000) 1-283; Mabeka Impact of E-Technology 52.

19 Cockram Interpretation of Statutes 1-22; De Ville Constitutional and Statutory Interpretation 1-283; Mabeka Impact of E-Technology 52; SCA The preamble.

20 Cockram Interpretation of Statutes 1-22; De Ville Constitutional and Statutory Interpretation 1-283; Mabeka Impact of E-Technology 52, s 3 of the CSA.

21 Kleyn and Viljoen Beginner's Guide for Law Students 85; Mabeka Impact of E-Technology 52; Peté et al Civil Procedure: A Practical Guide - Procedural Law 351. 
highest court in all matters. This puts the decisions of the Constitutional Court above all other decisions, in any matter granted leave to appeal to the Constitutional Court, and affirms the supremacy of the Constitution ${ }^{22}$ as intended by the drafters.

To expand on the authors' submissions regarding the impact of etechnology and related laws, the Constitutional Court will, as the apex court, set the pace for other courts to employ technology in its daily operations.

This amendment is important because proceedings in the Constitutional Court are recorded and court documents are still, to a certain extent, managed manually. Notwithstanding the current lack of full implementation of e-technology for court process, the authors submit that the amendment that brought about the apex jurisdiction will lead to proper implementation of e-technology legislation, particularly the ECTA, which enables courts to conduct processes using electronic or digital means. ${ }^{23}$

\section{RULES BOARD FOR COURTS OF LAW ACT 107 OF 1985 (RBCL ACT)}

The RBCL Act is significant because it establishes the Board and grants it extensive powers to draft and amend rules as it deems necessary. ${ }^{24}$ The RBCL Act provides for rules that facilitate the functioning of the various courts - namely, the superior and lower courts. It further regulates the way in which courts conduct their proceedings - for example, the execution of writs, and other court processes. ${ }^{25}$ The Board was created in terms of the Act, which reviews all the rules of the respective courts relating to practice and procedure, including the service of court documents. ${ }^{26}$ The Board thus has a fundamental role to play in accepting and expanding the use of e-technology in the court process in future.

\section{SUPERIOR COURTS ACT 10 OF 2013 (SC Act)}

The SC Act repealed the Supreme Court Act 59 of 1959. The thrust of the new legislation was to create one legislative instrument to regulate proceedings in the superior courts. ${ }^{27}$ The SC Act regulates different processes and proceedings in the Supreme Court of Appeal and the High Court. $^{28}$ It further provides for the appointment of court administrators such

22 Ibid.

23 CSA; Kleyn and Viljoen Beginner's Guide for Law Students 85; Mabeka Impact of ETechnology 53; Peté et al Civil Procedure: A Practical Guide - Procedural Law 351.

24 S 2 of the RBCL Act; Faris and Hurter The Student Handbook for Civil Procedure 31; Mabeka Impact of E-Technology 53; Peté et al Civil Procedure: A Practical Guide Procedural Law 12.

25 S 6 of the RBCL Act; Faris and Hurter The Student Handbook for Civil Procedure 31; Peté et al Civil Procedure: A Practical Guide - Procedural Law 12.

26 Ibid.

27 Faris and Hurter The Student Handbook for Civil Procedure 13-63; Peté et al Civil Procedure: A Practical Guide - Procedural Law 8-480; Van Blerk Preparation for Civil Trials 1ed (2019) 9.10-20.14.

28 Ibid. 
as judges and other officers responsible for the daily operation of the court. ${ }^{29}$

It further regulates how judges should deliver judgments and determines the quorum of the Supreme Court of Appeal and the High Court. ${ }^{30}$

The SC Act further sets out processes that must be followed before court documents are served and filed. In addition, when there is a need to call upon witnesses who will not testify in person, the Act allows parties to subpoena witnesses. Section 34 provides that court documents must be certified for them to be admissible as evidence before the court. ${ }^{31} \mathrm{~A}$ narrow interpretation of this provision points to an exclusion of the use of $\mathrm{e}$ technology devices when witnesses must appear in person. ${ }^{32}$ In $K v$ Transnet $L t d,{ }^{33}$ however, the court attempted to look past this narrow interpretation and allowed a witness to testify using video conferencing, thus expanding the methods by which a court hears evidence. Whitear-Nel supported this decision. ${ }^{34}$ Van Blerk posits that courts are indeed starting to follow a flexible approach when there is a need to use video-link to hear a witness who is otherwise unable to give evidence in person in court physically. ${ }^{35}$

The proffered narrow interpretation also applies to the subpoena duces tecum provided for by section 35 of the SC Act. There is no provision for the use of e-technology in the application of the subpoena duces tecum principle; a witness is subpoenaed only to produce the evidence required. ${ }^{36}$ However, if amended in line with ECTA, in future, the courts will not necessarily require witnesses to make a physical appearance to produce documents or evidence. ${ }^{37}$ This implies that sections 34 and 35 should be amended to support an electronic means of submission of evidence without a physical presence at court.

This amendment could also affect section 36 , which requires subpoenaed witnesses to give oral evidence and to answer questions posed, and which criminalises a refusal to comply with the subpoena duces tecum..$^{38}$ Currently, a defaulter may be imprisoned if he or she refuses to comply with section 36 subpoena requirements. If amended, however, a refusal based on logistical and geographical reasons may be overcome in the absence of other

29 S 11 of the SC Act; Faris and Hurter The Student Handbook for Civil Procedure 13; Peté et al Civil Procedure: A Practical Guide - Procedural Law 8-480; Mabeka Impact of ETechnology 53.

30 Ibid.

31 S 34 of the SC Act; Faris and Hurter The Student Handbook for Civil Procedure 24; Peté et al Civil Procedure: A Practical Guide - Procedural Law 8-480; Mabeka Impact of ETechnology 53.

32 Ss 54-55 of the SC Act; see also Mabeka Impact of E-Technology 53.

33 (2018) 4 All SA 251 (KZD).

34 Whitear-Nel "Video-Link Testimony in Civil Courts in South Africa: $K v$ Transnet Ltd T/A Portnet (KZD)" 2019 SALJ 136 245-260.

35 Van Blerk Preparation for Civil Trials 169.

36 Faris and Hurter The Student Handbook for Civil Procedure 24; Peté et al Civil Procedure: A Practical Guide - Procedural Law 281; Van Blerk Preparation for Civil Trials 18.10.

37 Ibid.

38 S 36 of the SC Act; Faris and Hurter The Student Handbook for Civil Procedure 25; Peté et al Civil Procedure: A Practical Guide - Procedural Law 280, 281 and 299. 
reasons for refusal.

Section 36, however, evinces a gap concerning the acceptance of digital or video-clips of oral evidence required when a person is subpoenaed in terms of the Act. A provision is thus required to accommodate digital or video-clips, Skype or any other means of communication using etechnology, whereby a witness may give oral evidence live in court proceedings without being physically present.

Section 39 deals with an examination by interrogatories. ${ }^{39}$ An examination by interrogatories is one of the ways in which evidence may be brought before a court in civil procedure. ${ }^{40}$ In practice, it means that a commissioner is given questions that the parties wish to put to the witness, ${ }^{41}$ and this ordinarily occurs where a witness is unable to appear physically in court because he or she resides outside the jurisdiction of the court hearing the matter. ${ }^{42}$

There are electronic means of communication such as Skype, CCTV or video conference that can be used to facilitate the use of interrogatories in court proceedings. For example, a commissioner could allow a witness to give evidence directly through an electronic means of communication, and by way of technology, the witness's answers would be recorded onto a device or disk, and such media would then be produced in court. The memory stick or CD should be presented to the Registrar and should be stored for the record of the court. Moreover, the use of technology devices or instruments in the trial would circumvent the need for interrogatories. Thus, interrogatories would effectively become obsolete because witnesses would testify directly or via online communication. This would ultimately also serve as a cost-saving exercise for the Department of Justice and Constitutional Development.

Faris and Hurter affirm that the duties of sheriffs entail the execution of court processes as provided for in section 43 of the Act. ${ }^{43}$ This provision may require amendment in future where action and summons proceedings are commenced and effected via ECTA preferably, as opposed to service by the sheriff as is currently required.

There may not be a need to use the services of sheriffs in future if the rules are amended to incorporate electronic service and return; much like the position of interrogatories, this would reduce the fiscal demand on the Department of Justice and Constitutional Development (not to mention the ease of service that would be facilitated by such an amendment).

Furthermore, the impact of e-technology in the future will not only affect

9 Mabeka Impact of E-Technology 55, s 39 of the SC Act.

40 S 39 of the SC Act; Faris and Hurter The Student Handbook for Civil Procedure 25; Van Blerk Preparation for Civil Trials 20.1 and 20.14; Mabeka Impact of E-Technology 55.

41 Broodryk Eckard's Principles of Civil Procedure in the Magistrates' Court 210; s 52 of the MCA.

42 Whitear-Nel 2019 SALJ 245-260; K v Transnet Ltd supra; Mabeka Impact of E-Technology 55; Peté et al Civil Procedure: A Practical Guide - Procedural Law 697.

43 Faris and Hurter The Student Handbook for Civil Procedure 27; see also Mabeka Impact of E-Technology 55. 
the position of sheriffs but also other processes conducted by officials of the court - for example, the taxation of party-and-party costs by the Registrar. The future use of e-technology implies that taxation could be conducted electronically, which means that the parties and the Registrar would use teleconference or video-link to conduct the taxation process instead of needing the physical appearance of the parties. In addition, the parties would submit taxation documents via email so that both the Registrar and the other party or parties are able to peruse the documents during the process. Naturally, this requires an amendment of the current rule(s) regarding taxation and verification of the services provided to the legal practitioner's client in practice up until the civil trial ends.

\section{MAGISTRATES' COURTS ACT 32 OF 1944 (MCA)}

According to the MCA, magistrates' courts are creatures of statute and thus jurisdiction is determined by the enabling statute. There are various provisions of the Act that would be affected by the use of e-technology. The point of departure here is section 14, which provides for the appointment of sheriffs of the court. ${ }^{44}$

Prior to legislative amendment, messengers of the court served and executed court documents but these officials are now referred to as sheriffs of the court. 45 The position of messengers of the court changed when the Sheriffs Act ${ }^{46}$ was passed. ${ }^{47}$ The future existence of sheriffs may be affected by the implementation of ECTA, particularly insofar as the service of court processes using electronic means or e-technology as discussed above is concerned.

If such amendment brings about the repeal of the office of the sheriff, it is submitted that sheriffs should be absorbed into any new system promoting the use of digital devices. ${ }^{48}$ While traditional sheriffs will no longer be necessary if court documents can be served, filed and executed via electronic means, ${ }^{49}$ the authors submit that use of a similar office should be accommodated to serve those who do not have access to e-technology,

44 S 14 of the MCA; Broodryk Eckard's Principles of Civil Procedure in the Magistrates' Courts 8-10; Faris and Hurter The Student Handbook for Civil Procedure 139; see also Mabeka Impact of E-Technology 56.

45 Ibid.

4690 of 1986.

47 S 64(2) (a)-(b) of the SA; Broodryk Eckard's Principles of Civil Procedure in the Magistrates' Courts 8-10; Mabeka Impact of E-Technology 57; Peté et al Civil Procedure: A Practical Guide - Procedural Law 133-134.

48 Ramotsho "Gauteng High Courts on a Journey to Go Paperless" (21 October 2019) http://www.derebus.org.za/gauteng-high-courts-on-a-journey-to-go-paperless/ (accessed 2019-11-14); Mabeka Impact of E-Technology 57; Swales "An Analysis of the Regulatory Environment Governing Hearsay Electronic Evidence in South Africa: Suggestions for Reform - Part One" 201821 PER 1-30; K v Transnet Ltd supra.

49 According to Ramotsho, there is a Caseline system that Judge President Mlambo has been preaching about, and which the Gauteng High Courts are gearing towards in the future, that will result in courts doing away with paperwork; Ramotsho http://www.derebus.org.za/gauteng-high-courts-on-a-journey-to-go-paperless/; Mabeka Impact of E-Technology 57. 
particularly in the rural areas. ${ }^{50}$ Sheriffs have extensive experience and phasing out their services will in the future have dire consequences on individual sheriffs, their families whom they financially support will be adversely affected if they are phased out. A proposed centralised system for electronic service and return, in compliance with ECTA, could incorporate sheriffs trained in new ways of serving process. It is prudent to note that the existence of the sheriffs should be preserved to assist in the use of digital or e-technology to effect court processes in future.

The same position expressed with regard to sheriffs applies to section 17 of the MCA ${ }^{51}$ which refers to evidence to prove service. In future, perhaps an electronic system could be used to draft returns of service for distribution electronically instead of having to submit original copies of the certificate of service as proof that service was effected. Naturally, any such change would require that authenticity be proved but these concerns are not relevant to the argument here and are aspects that could be addressed after implementing an amendment to incorporate such provisions as suggested by the authors.

Section 31 and 32 of the MCA provide for an automatic rent interdict and attachment of property to effect the hypothec..$^{52}$ Currently, the sheriffs of the court conduct the process of issuing summons for automatic rent interdict manually. Following the same arguments proffered above, these provisions could be amended to include electronic methods of issuing summons, which may be served and filed using e-technology. ${ }^{53}$

Moreover, sections $51,52,53$ and 54 of the $\mathrm{MCA}^{54}$ deserve further scrutiny because they speak to the manner in which evidence is secured in court proceedings. These sections deal with different methods of ensuring that witnesses testify in court where and when necessary, as is the case in

50 National Center for State Courts "Rural Courts Resource" (10 June 2017) http://www.ncsc.org/Topics/Special-Jurisdiction/Rural-Courts/Resource-Guide.aspx (accessed 2017-11-12).

51 See Anthony and Berryman Magistrates' Court Guide 1145-1183; Broodryk Eckard's Principles of Civil Procedure in the Magistrates' Courts 1-438; Cilliers et al Herbstein and Van Winsen: The Civil Practice of the High Courts and the Supreme Court of Appeal of South Africa 1-2000; Erasmus and Van Loggerenberg Jones and Buckle: The Civil Practice of the Magistrates' Court in South Africa 21-80; Kelbrick and Cassim Civil Procedure in South Africa 1-146; Faris and Hurter The Student Handbook for Civil Procedure 344-345; Peté et al Civil Procedure: A Practical Guide - Procedural Law 52-268; Mabeka Impact of E-Technology 57.

52 Ss 30-33 of the MCA; Anthony and Berryman Magistrates' Court Guide 1145-1183; Erasmus and Van Loggerenberg Jones and Buckle: The Civil Practice of the Magistrates Court in South Africa 21-80; Kelbrick and Cassim Civil Procedure in South Africa 1-146; Mabeka Impact of E-Technology 57.

53 Erasmus and Van Loggerenberg Jones and Buckle: The Civil Practice of the Magistrates Court in South Africa 21-80; Kelbrick and Cassim Civil Procedure in South Africa 1-146; Faris and Hurter The Student Handbook for Civil Procedure 135-159; Peté et al Civil Procedure: A Practical Guide - Procedural Law 52-268; Mabeka Impact of E-Technology 57.

54 See Erasmus and Van Loggerenberg Jones and Buckle: The Civil Practice of the Magistrates' Court in South Africa 21-80; Faris and Hurter The Student Handbook for Civil Procedure 135-159; Peté et al Civil Procedure: A Practical Guide - Procedural Law 52268; Mabeka Impact of E-Technology 58. 
section 43 of the SC Act. ${ }^{55}$ Section 51 of the MCA provides for the issue of a subpoena and subpoena duces tecum when necessary, and requires witnesses to give evidence or to bring evidence before court using interrogatories, as is the case in the SC Act. Section 53 of the MCA facilitates other means of effecting evidence in court through commissions de bene esse, which are similar to interrogatories. ${ }^{56}$

Section 54 of the MCA provides that the court may call upon parties to conduct pre-trial proceedings when the court is of the view that it is necessary to do so, ${ }^{57}$ or when there is a written request for such. The civil proceeding process involves narrowing down issues and deciding on relevant evidence to be presented during proceedings. ${ }^{58}$ It eliminates irrelevant issues and expedites court proceedings. ${ }^{59}$

In practice, this process is conducted in the form of a meeting in a venue decided upon by the parties; often, the "[c]onference takes place in the chambers of the most senior advocate involved in a matter". ${ }^{60}$ These provisions will, in future, be affected because, for example, there will be no need for the parties to meet to conduct a pre-trial conference physically. The same applies to interrogatories; if there is digital evidence, there is no need to use commissioners to ask witnesses questions to gather evidence. ${ }^{61}$ Skype and live digital CCTV can be used during court proceedings to examine and cross-examine witnesses and their evidence. E-technology can be used before, during and after a civil trial.62 The authors argue that the Department of Justice and Constitutional Development is responsible for providing and maintaining such facilities in the pursuit of justice.

Another significant provision of the MCA relates to the admission of liability, which enables a debtor to pay a debt in instalments through a

55 Harms Civil Procedures in Magistrates' Court Part C (2016) C-10; Mabeka Impact of ETechnology 58.

56 Erasmus and Van Loggerenberg Jones and Buckle: The Civil Practice of the Magistrates' Court in South Africa 21-80; Peté et al Civil Procedure: A Practical Guide - Procedural Law 292-697; Mabeka Impact of E-Technology 59.

57 Anthony and Berryman Magistrates' Court Guide 1145-1183; Broodryk Eckard's Principles of Civil Procedure in the Magistrates' Courts 1-438; Cilliers et al Herbstein and Van Winsen: The Civil Practice of the High Courts and the Supreme Court of Appeal of South Africa 1-2000; Erasmus and Van Loggerenberg Jones and Buckle: The Civil Practice of the Magistrates' Court in South Africa 21-80; Kelbrick and Cassim Civil Procedure in South Africa 1-146; Faris and Hurter The Student Handbook for Civil Procedure 135-159; Peté et al Civil Procedure: A Practical Guide - Procedural Law 52-268; Mabeka Impact of ETechnology 59.

58 Erasmus and Van Loggerenberg Jones and Buckle: The Civil Practice of the Magistrates' Court in South Africa 21-80; Faris and Hurter The Student Handbook for Civil Procedure 135-159; Mabeka Impact of E-Technology 63.

59 S 54(1)(a) of the MCA; Mabeka Impact of E-Technology 59-63.

60 Harms Civil Procedures in Magistrates' Court (2016) C-10; Mabeka Impact of ETechnology 59; Peté et al Civil Procedure: A Practical Guide - Procedural Law 292.

61 Harms Civil Procedures in Magistrates' Court (2016) C-10; Mabeka Impact of ETechnology 60; Peté et al Civil Procedure: A Practical Guide - Procedural Law 292.

62 Erasmus and Van Loggerenberg Jones and Buckle: The Civil Practice of the Magistrates' Court in South Africa 21-80; Kelbrick and Cassim Civil Procedure in South Africa 1-146; Faris and Hurter The Student Handbook for Civil Procedure 135-159; Mabeka Impact of ETechnology 58. 
written undertaking. The request for such undertaking, according to section 57 , must be sent to the debtor by registered mail. ${ }^{63}$ Without exploring the peculiarities of the South African postal service, it is perhaps trite to state that the postal service has become defunct by virtue of inefficiency. In contemporary society, most business communication occurs via email. Registered mail has fallen into disuse and has thus become obsolete, and even when used is ineffective. The provisions of section 57 must, therefore, be amended to accommodate the use of electronic communication such as email, as opposed to registered mail, in pursuance of section 57 process. While it is borne in mind that some parties prefer to send documents by registered mail, it appears that there is a need to replace registered mail with suitable electronic forms of delivery.

The authors' view is supported by the recent introduction of the digital Caselines by the High Court in the Gauteng Province. ${ }^{64}$ Justice, in this instance, is enhancing the efficiency and certainty over outmoded rules for delivery. While those who prefer registered mail (perhaps for example in rural areas) must be accommodated, the rules of court should be progressive enough to embrace e-technology as a viable parallel to effect service. Other provisions of the MCA relating to the use of registered mail must likewise be amended in accordance with ECTA. 65

A narrow interpretation of section 74(4) of the MCA demonstrates a need to amend the manner of effecting service of court documents in line with ECTA. Section $74(Q)(4)^{66}$ may also require amendment as it currently requires personal service of rescission of judgment. These provisions ought to incorporate electronic means of service and delivery of court documents.

The overall implication of the above arguments for civil procedure is that summons, pleadings, affidavits, notices and all related court documents should, in future, be sent electronically as opposed to requiring physical delivery to the parties' physical addresses - with allowance being made for exceptional circumstances where e-technology is not available in a particular area or case. The authors reiterate that electronic and physical service can run as parallel options to effect service so as not to exclude those who do not have access to digital means of communication.

\section{THE SHERIFFS ACT 90 OF 1986 (SA)}

The main purpose of the SA is the creation of a process to employ sheriffs and to enforce their duties and responsibilities, which include effective

Ibid.

Ramotsho http://www.derebus.org.za/gauteng-high-courts-on-a-journey-to-go-paperless/.

65 Ss 74(1)(4)(Q) of the MCA; Broodryk Eckard's Principles of Civil Procedure in the Magistrates' Courts 350-351.

66 Broodryk Eckard's Principles of Civil Procedure in the Magistrates' Courts 350-351; Faris and Hurter The Student Handbook for Civil Procedure 135-159; MCA; Mabeka Impact of ETechnology 63. 
service of court documents. ${ }^{67}$ There is no doubt that sheriffs of the court play a significant role in ensuring that court processes and proceedings run smoothly. However, there are implications to the enhancement and enforcement of e-technology legislation that will affect the future role played by sheriffs in the South African court system. ${ }^{68}$ It is therefore important to consider the relevant provisions of the SA. The authors' point of departure is section 2 of the Act.

Section 2 provides for processes followed in appointing sheriffs. 69 The Minister appoints deputy sheriffs in consultation with the Board for Sheriffs in the superior and lower courts. ${ }^{70}$ Appointment of ordinary sheriffs does not require consultation with the Board. Consultation is required for senior positions, such as in the case of the appointment of deputy sheriffs. ${ }^{71}$

The continued existence of the Board for Sheriffs will be challenged by advancing technology, which in future will affect the manner in which sheriffs execute their duties. Essentially, the role of sheriffs may in future fall under the management of the Registrar of the courts (especially if the Caselines system, as mentioned earlier, is deemed appropriate and effective).$^{72}$ The composition of the Board in future may call for the inclusion of experts in information communication and technology as part of the decision-making process to ensure proficiency in running any electronic system created to serve court process.

If, for example, service is effected via electronic means, sheriffs cannot be held accountable for system problems or hardware failure. It would be unfair to hold sheriffs responsible for system glitches where there is evidence from one of the parties to the civil proceedings that confirms that service or attachment of property was effected electronically. In essence, sections 43 to 52 of the SA should be amended to incorporate service via etechnology..$^{73}$ These provisions will result in changes in how the return of service is effected, and to all other duties that sheriffs are required to

67 The Preamble of the SA; Broodryk Eckard's Principles of Civil Procedure in the Magistrates' Courts 8-10; see Mabeka Impact of E-Technology 61-65; Peté et al Civil Procedure: A Practical Guide - Procedural Law 133-134.

68 Ss $2-15$ of the SA; Broodryk Eckard's Principles of Civil Procedure in the Magistrates' Courts 8-10; see Mabeka Impact of E-Technology 61.

69 Ss 2-6 of the SA; Broodryk Eckard's Principles of Civil Procedure in the Magistrates' Courts 8-10; Peté et al Civil Procedure: A Practical Guide - Procedural Law 133-134; Mabeka Impact of E-Technology 61.

70 S 6 of the SA; Broodryk Eckard's Principles of Civil Procedure in the Magistrates' Courts 810; Peté et al Civil Procedure: A Practical Guide - Procedural Law 133-134.

71 See ss 2-6 of the SA; Broodryk Eckard's Principles of Civil Procedure in the Magistrates' Courts 8-10; Peté et al Civil Procedure: A Practical Guide - Procedural Law 133-134; Mabeka Impact of E-Technology 62.

72 Ibid.

72 Ramotsho http://www.derebus.org.za/gauteng-high-courts-on-a-journey-to-go-paperless/.

73 Ss 43 and 52 of the SA; Broodryk Eckard's Principles of Civil Procedure in the Magistrates' Courts 8-10; Peté et al Civil Procedure: A Practical Guide - Procedural Law 133-134; Mabeka Impact of E-Technology 62. 
execute in civil proceedings. ${ }^{74}$

\section{CONSUMER PROTECTION ACT 66 OF 2008 (CPA)}

The CPA enables parties to address and deal with their differences before embarking on formal processes in consumer disputes. It forces parties to use alternative dispute resolution before approaching a court to intervene. There is a body that was created in terms of section 26 of the NCA, to resolve disputes relating to credit, consumer, and market agreements. ${ }^{75}$

The primary purpose of drafting and passing the CPA was to protect the integrity of business and consumers by ensuring processes to resolve disputes arising from commercial agreements. ${ }^{76}$ The Act enforces international standards that protect consumer rights in international commercial agreements. ${ }^{77}$ The Act was intended to protect the rights of historically vulnerable consumers and provide for efficient remedies. ${ }^{78}$ The Act provides that when parties do not come to an agreement via alternative dispute resolution, they may commence formal court proceedings by issuing summons. ${ }^{79}$

Section 106(1) of the CPA enables the party that is required to submit information to the Tribunal or Commission to assert that the information is confidential. In terms of section 106(2), such a claim must be supported by a written statement explaining why such information is confidential. A narrow and contextual interpretation, however, demonstrates a breach in the implementation of sections $50^{80}$ and $51^{81}$ of ECTA. Both these sections promote the protection of personal information by setting out the manner in which the latter may be disclosed. ${ }^{82}$ For example, personal information may be disclosed if consent is given for such disclosure. ${ }^{83}$ In addition, personal information may be collected when the person whose information is affected provides articulated authority. ${ }^{84}$ The same applies to processing the information - there must be consent. ${ }^{85}$ Section 106 of the CPA may be

74 S 43 of the SA; Broodryk Eckard's Principles of Civil Procedure in the Magistrates' Courts 8-10; Peté et al Civil Procedure: A Practical Guide - Procedural Law 133-134; Mabeka Impact of E-Technology 62.

75 Mabeka Impact of E-Technology 63.

76 See Preamble of the CPA.

77 Broodryk Eckard's Principles of Civil Procedure in the Magistrates' Courts 18; Mabeka Impact of E-Technology 81.

78 The Preamble (a)-(b) of the CPA; Broodryk Eckard's Principles of Civil Procedure in the Magistrates' Courts 18; see also Mabeka Impact of E-Technology 63.

79 S 102 of the CPA; Broodryk Eckard's Principles of Civil Procedure in the Magistrates' Courts 18

$80 \mathrm{~S} 50$ of ECTA deals with the scope of protection of personal information.

81 S 51 of ECTA provides for the manner in which personal information that is electronically collected may be dealt with in terms of ECTA.

$82 \mathrm{~S} 50$ and 51 of ECTA.

$83 \mathrm{~S} 51$ of ECTA.

84 S 51(1) of ECTA.

$85 \mathrm{~S} 51(1)$ of ECTA. 
construed as hindering the discovery process available to parties in civil proceedings because, when the information is officially declared confidential in terms of this section, such information may not be used in the trial proceedings.

This may disadvantage the party declaring the information in future civil proceedings. The court may, in terms of the rules, force the party who has already declared the information confidential in the Tribunal, to disclose such information. In the alternative, the court can dismiss the claim in civil proceedings. ${ }^{86}$

There is a need therefore to incorporate provisions in ECTA that will dissuade parties from discovering information in future civil proceedings, especially in situations where information was declared confidential in Tribunal proceedings.

Section 102 of the CPA enables the Commissioner to issue summons to a person who may be able to provide evidence during the investigation process. ${ }^{87}$ The manner of service is effected in the same manner as other court documents; the sheriff of the respective court serves the summons. ${ }^{88}$ This section further requires that a party in possession of documents necessary for the investigation, before and during the Tribunal, must present such documents to the Commission. The required manner of delivery of documents is not articulated by section 102(1) of the CPA. ${ }^{89}$ In addition, there is no accommodation for presenting such documents or books using etechnology or electronic communication. ${ }^{90}$ It is observed that there is a need to review section 102 in order to incorporate e-technology and an electronic means of effecting civil process. The Act should allow delivery by way of email, for example.

Section 115 provides for processes followed during civil proceedings and determination of jurisdiction. ${ }^{91}$ It requires parties to file a notice commencing proceedings with the clerk of the court. ${ }^{92}$ The manner of filing such notice, however, is not provided for in this provision, and there is no indication that filing can be conducted by electronic means of communication or etechnology. The authors, therefore, opine that there is a need to amend the provision to incorporate e-technology or electronic means of filing with the clerk of the court. The same applies to section 118, which deals with the manner of serving documents. In terms of this section, proper service occurs when the document is delivered to the relevant party, or is sent by registered mail to the person's last known address. This is significant not only for

36 See Rule 37 of the Uniform Rules of Court, Mabeka Impact of E-Technology 64.

87 S 102 of the CPA; Peté et al Civil Procedure: A Practical Guide - Procedural Law 524-528; Mabeka Impact of E-Technology 64.

$88 \mathrm{~S} 102(2)$ of the CPA.

$89 \mathrm{~S} 102(1)$ of the CPA.

90 S 102 of the CPA; Peté et al Civil Procedure: A Practical Guide - Procedural Law 524-528; Mabeka Impact of E-Technology 64.

91 Broodryk Eckard's Principles of Civil Procedure in the Magistrates' Courts 18; Peté et al Civil Procedure: A Practical Guide - Procedural Law 524-528; see Mabeka Impact of ETechnology 65.

92 S 106 of the CPA. 
arguments evinced earlier as to efficiency but also because logistically people move abode from time to time ${ }^{93}$ and the last known address that the creditor is required to use may be an address that the debtor no longer uses. ${ }^{94}$

Further to the above, the word "must", as used in the provisions of sections 115 and 118 of the CPA, is important from the perspective of the interpretation of statutes. ${ }^{95}$ This provision requires scrutiny in that it does not make provision for service using e-technology, as provided for by ECTA, and thus limits service to in-person service or registered mail, ${ }^{96}$ both of which, as discussed earlier, present challenges to efficiency and logistics.

"Must" indicates that this provision is mandatory. Therefore, there is no flexibility regarding its application and enforcement. ${ }^{97}$ There is, therefore, a clear need to amend this provision and incorporate the relevant provisions of ECTA, as well as the guideline drafted by the Law Society of South Africa concerning the use of e-technology, in the court process. An interpretation of this provision that considers the intention of the legislature confirms the gap as identified in the enforcement of ECTA as far as civil proceedings and processes are concerned. ${ }^{98}$

\section{NATIONAL CREDIT ACT 34 OF 2005 (NCA)}

The NCA came into effect on 1 June 2007. The use or misuse of credit affects many South Africans because the consumer industry is vast and convoluted in its regulations. Before the ushering in of a democratic government in 1994, it was difficult for people who came from disadvantaged backgrounds to access credit; and a lack of information on the responsible use of credit has had a drastic impact on many consumers in the postapartheid era. The Act was promulgated to educate consumers on how to use and manage credit responsibly.

The significant provisions of the Act, as they relate to the implementation of ECTA, are sections 129, 130, 162, 164, and $168 .{ }^{99}$

Section 129(1)(a) requires a lender who has not received payment to issue a notice to the consumer before instituting civil proceedings. ${ }^{100} \mathrm{~A}$

93 Unpacktblog "Top 12 Reasons Why People Move to a New Home" http://www.blog.unpakt.com (accessed 2019-11-14).

94 lbid.

95 Peté et al Civil Procedure: A Practical Guide - Procedural Law 510-528; Mabeka Impact of E-Technology 91.

96 Peté et al Civil Procedure: A Practical Guide - Procedural Law 510-528; Mabeka Impact of E-Technology 65; see also s 118 of the CPA.

97 S 115 of the CPA; Broodryk Eckard's Principles of Civil Procedure in the Magistrates' Courts 18; Peté et al Civil Procedure: A Practical Guide - Procedural Law 524-528.

$98 \mathrm{~S} 118$ of the CPA.

99 Broodryk Eckard's Principles of Civil Procedure in the Magistrates' Courts 18; Peté et al Civil Procedure: A Practical Guide - Procedural Law 524-528; Mabeka Impact of ETechnology 66.

100 See ss $129-169$ of the NCA; Mohale "Protection Offered by $s 129$ of the National Credit Act" 2016 De Rebus 23; Peté et al Civil Procedure: A Practical Guide - Procedural Law 510 521; Mabeka Impact of E-Technology 66. 
narrow and grammatical interpretation of the use of the word "may" indicates that this is not mandatory.

A contextual interpretation, however, illustrates that section 129(1)(b) makes the process of issuing notice compulsory because it provides that parties may not institute legal proceedings without first issuing a notice. This provision, however, does not determine the manner of service on the defaulting debtor, which is problematic. ${ }^{101}$ In Kubyana $v$ Standard Bank of South Africa $L t d,{ }^{102}$ the notice was sent by registered mail to the address indicated in the credit agreement, but was returned, which slowed the process; it also goes to evince the inefficiency of registered mail as a manner of service. The Constitutional Court considered the importance of issuing a notice in terms of section 129 of the NCA and confirmed that notice must be delivered to the last known address. ${ }^{103}$

The above case demonstrates the potential use of electronic means of service and delivery and further points to the efficiency of such mechanisms, which would ensure delivery regardless of a defaulting debtor's geographic location. ${ }^{104}$ In the absence of an amendment, the creditor would have difficulty proving that it has taken all the necessary steps to ensure effective delivery of the notice if the provision itself does not provide for other means to effect same. The latter is evinced bearing in mind that some do not have means to use electronic means or technology, particularly in the rural areas; and the authors proffer the same solutions to this challenge as discussed earlier.

It is argued that when interpreting section 129(1) of the NCA, it must be read with section 168 to reach a conclusion. ${ }^{105}$ Mohale, on the other hand, emphasises the need to protect consumers by arguing for compliance with section 129 of the NCA. ${ }^{106}$ Thus, currently, the law compels parties to issue a notice before civil proceedings are instituted. There is, therefore, a need to amend section 129 to ensure that the notice (authors' emphasis) should be issued electronically or by email or by other technological means, in case the debtor has moved and changed addresses without notifying the creditor.

Section 168 of the NCA states:

"Unless otherwise provided in this Act, a notice, order or other document that, in terms of this Act, must be served on a person will have been properly served when it has been either-

(a) delivered to that person; or

101 S 129 of the NCA; Broodryk Eckard's Principles of Civil Procedure in the Magistrates' Courts 18; Peté et al Civil Procedure: A Practical Guide - Procedural Law 524-528; Mabeka Impact of E-Technology 67.

102 (2014) 4 BCLR 400 (CC).

103 Broodryk Eckard's Principles of Civil Procedure in the Magistrates' Courts 18; Peté et al Civil Procedure: A Practical Guide - Procedural Law 524-528; Mabeka Impact of ETechnology 101.

104 Broodryk Eckard's Principles of Civil Procedure in the Magistrates' Courts 18; Peté et al Civil Procedure: A Practical Guide - Procedural Law 524-528; Mabeka Impact of ETechnology 67.

105 Ibid.

106 Mohale 2016 De Rebus 23; see also Mabeka Impact of E-Technology 67. 
(b) sent by registered mail to that person's last known address."

The general principles of interpretation show that the use of electronic service was not contemplated in the above section. Put differently, the meaning demonstrates that the legislature did not intend to consider electronic service of notice at the time of drafting the statute. ${ }^{107}$ The provisions themselves are challenging because people may move from one country to another. ${ }^{108}$ It is argued that if people are not aware of a notice issued in this regard, and if a default judgment is subsequently granted against them, they will be prejudiced.

The Constitutional Court confirmed the significance of following section 129 in Baliso $v$ Firstrand Bank Limited t/a Wesbank. ${ }^{109}$ In this case, the notice required in terms of section 129 of the NCA was sent by ordinary mail. The Constitutional Court considered both sections 129 and 130 and held that non-compliance with section 129 was not acceptable and that parties, therefore, could not go ahead with civil litigation unless they followed these provisions. The authors, however, argue that it is insufficient to effect service of notice merely by personal service or registered mail, especially in a world where mobility is enhanced and people move location frequently, often without notice to creditors. The situation would be better solved through the use of already existing e-technology laws to prevent prejudice. Certain provisions of ECTA, for example, would, if properly implemented, ensure effective delivery and service.

Section 130 of the Act is equally important. It provides that a creditor can only institute legal proceedings when there is a default for payment after 20 working days, and only if 10 working days have elapsed since a notice was delivered. ${ }^{110}$ This is once again a challenge because the manner of delivery of the notice in question is not provided for, and it is evident that the legislature did not have ECTA in mind when drafting these provisions.

If the legislature had these provisions in mind, it would have permitted and enabled electronic means and other e-technology facilities for delivery of notices. As a result, there are now more default judgments taken against debtors that are unknown to them (this is also the case where the debtor did not cause the default in the first instance), which demonstrates the potential prejudice to both debtors and creditors. It is evident that these provisions must be amended to incorporate e-technology or electronic means for delivery of a notice to ensure fairness in civil proceedings.

107 S 168 of the NCA; De Ville Constitutional and Statutory Interpretation 1-94; Singh and Bhero "Judicial Law-Making: Unlocking the Creative Powers of Judges in Terms of Section 39(2) of the Constitution" 2016 PER 1727-3781; Mabeka Impact of E-Technology 68.

108 Unpacktblog http://www.blog.unpakt.com; Mabeka Impact of E-Technology 68; see also The South African "South Africans Move to Australia" (2014) http://www.thesouthafrican.com/South-Africans-moving-toAustralia (accessed 2019-03-27).

109 (2017) 1 SA 292 (CC).

110 S 130 of the NCA; Broodryk Eckard's Principles of Civil Procedure in the Magistrates' Courts 18; Faris and Hurter The Student Handbook for Civil Procedure 343-346; Peté et al Civil Procedure: A Practical Guide - Procedural Law 524-528; Mabeka Impact of ETechnology 68. 


\section{SMALL CLAIMS COURT ACT 61 OF 1984 (SCC Act)}

The SCC Act was introduced to enable parties with less substantial claims sounding in money to access the civil process more affordably. The Act was passed to enable parties who cannot afford legal fees access to legal recourse when they have disputes that can be handled by the small claims courts. ${ }^{111}$ The small claims courts have limited jurisdiction; the Minister, from time to time, determines the amount in terms of the Act. ${ }^{112}$ The amount currently is R 20000 . These courts cannot decide claims that exceed their jurisdiction in terms of this determination. ${ }^{113}$

Proceedings are presided over by a commissioner, and the parties represent themselves. ${ }^{114}$ It appears that these courts expedite civil litigation and therefore save time and costs for all parties to a matter. As in the magistrates' courts, the small claims courts use the services of messengers and other officers to serve documents necessary for the proceedings. ${ }^{115}$ Section 3 of the SCC Act, however, recognises the use of e-technology devices in that it enables the use of a recording of the proceedings. ${ }^{116}$

Another pertinent provision is section 11 of the SCC Act, which requires the sheriffs of the magistrates' courts to perform the same duties in the small claims courts. ${ }^{117}$ The process provided for in the MCA for service of a summons and court documents is similar in the small claims court. ${ }^{118}$

Section 11 obliges the service of the summons to be effected personally. ${ }^{119}$

A narrow and contextual interpretation of section 29 of the SCC Act intimates that the use of the word "shall" denotes mandatory personal service. Section 29 further provides for personal service or service via registered mail, both of which garner the same criticism as provided for earlier in this submission. The authors maintain that registered mail should only be used in exceptional circumstances where parties can show that they have no means of using technology, for reasons beyond their control. ${ }^{120}$

\footnotetext{
S 7(1) and (2) of the SCC Act; see also Mabeka Impact of E-Technology 70.

12 See ss 15 and 16 of the SCC Act.

113 Department of Justice "Determination of Amount for Purposes of Sections 15 and 16 of the Small Claims Court Act, 1984" http://www.justice.gov.za (accessed 2019-11-14); Sabinet "Monetary Jurisdiction of Small Claims Courts Set to Increase" (27 February 2019) http://www.golegal.co.za (accessed 2019-11-14); Mabeka Impact of E-Technology 70; Peté et al Civil Procedure: A Practical Guide - Procedural Law 484.

114 S 8 of the SCC Act.

115 Rule 8 and 9 of the Magistrates' Courts Rules; and the Small Claims Courts Rules.

$116 \mathrm{~S} 3$ of the SCC Act.

117 S 11 of the SCC Act; Magistrates' Courts Rules.

118 See Rule 4 and 13 of the Rules Regulating Matters in Respect of Small Claims Court of April 1991.

119 See Mabeka Impact of E-Technology 130.

120 CMC Woodworking Machinery v Odendaal Kitchens supra par 1; Mabeka Impact of ETechnology 72.
} 


\section{DIVORCE ACT 70 OF 1979}

The Divorce Act was passed to amend the laws that regulate divorce proceedings $^{121}$ and to expedite processes incidental thereto. The Act sets out grounds for jurisdiction ${ }^{122}$ and the grounds that assist the court to decide on a divorce matter brought before it. ${ }^{123}$ It further highlights the process followed when assets are divided. ${ }^{124}$ The relevant provision relating to the implementation of e-technology law is section 11. Section 11 states that the divorce procedure applicable shall be prescribed, from time to time, by the rules of court. ${ }^{125} \mathrm{~A}$ contextual interpretation of this provision is problematic because it does not necessarily recognise procedures regulated by other statutes such as ECTA. However, the courts follow a flexible approach as demonstrated in CMC Woodworking Machinery $v$ Odendaal Kitchens, ${ }^{126}$ where the court allowed service of process via Facebook. While such flexibility is encouraged and welcomed, the authors argue that the procedure for electronic service and the rule regulating it should be prescribed by the Act, read together with the relevant provisions of ECTA in order to ensure formality of procedure.

\section{RECOMMENDATIONS AND CONCLUSION}

It is observed that, soon, most (if not all) court processes will be conducted by electronic communication, including the filing of court documents. This will necessitate the installation of satellite dishes by government departments in both rural and urban areas, particularly in courts where the proposed digital centralised department will operate. This will efficiently facilitate the processes of the law of civil procedure and will ensure compliance with ECTA and other e-technology laws.

It is further proposed that e-technology should be designed in a manner that enables any party to access information relating to civil proceedings and to track progress made in individual cases. The system should incorporate pop-up messages to indicate due dates for different court processes. For example, after a plaintiff files a notice of motion, the defendant has ten days to file a notice to defend the matter. It would be advantageous to have popup messages as a reminder of subsequent processes in terms of the rules. The South African judiciary and legislature must ensure that there is adequate budget available to implement e-technology law successfully. This would be boosted by having professional and accredited service providers and data controllers to deal with court files, avoid breaches of confidentiality, and facilitate efficient and effective court proceedings.

In conclusion and given the discussion in this article, the authors express

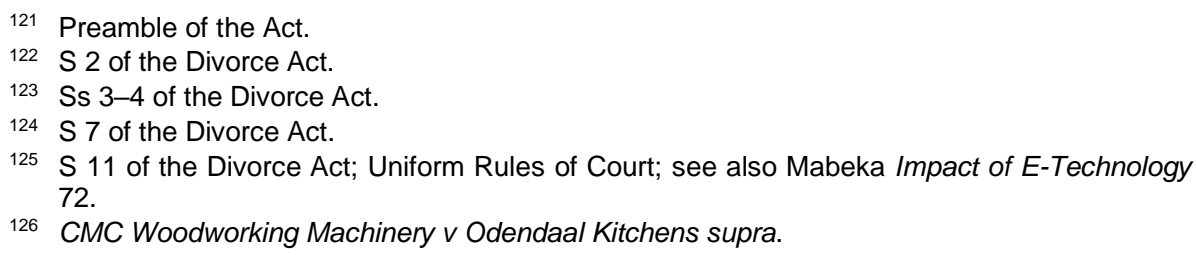


the view that there is a need to amend the current laws of civil procedure to ensure their alignment with e-technology laws and ECTA. It is submitted that Parliament should consider drafting the amendments for the provisions identified herein. In addition, the authors assert that the time has come to develop the law of civil procedure in line with e-technology and digital devices to save both the courts and the parties time and thus facilitate a speedy resolution of proceedings. 